\section{Influencing factors of the plate glass columns on the load bearing capacity}

ANDRÁs JAKAB - BME Department of Construction Materials and Technologies - jakab.andras@epito.bme.hu

Salem Georges NEHME - BME Department of Construction Materials and Technologies - sgnehme@yahoo.com

Érkezett: 2018. 03. 21. - Received: 21. 03. 2018. - https://doi.org/10.14382/epitoanyag-jsbcm.2018.12

\section{Abstract}

The initial imperfection of the structural elements must be taken into account in case of the modern building designing. These imperfections are local or overall defects of the glass elements. These defects are able to reduce significantly the load bearing capacity and the stability limits as well. The initial curvature and the imperfections of the elements are taken into account at the stability designing in case of the general building materials. The applied limits depended on the cross-section of the structural elements. Glass designing for load bearing elements has been applied since a few decades, however there are limits for initial imperfections. More than 240 small scaled l-shaped glass columns were loaded until fracture under laboratory conditions. The lateral buckling was investigated based on the individual experimental procedure. One of the most important properties of the glass columns are the initial imperfections. The higher overall bow and roller wave values can cause disadvantages at the load bearing capacity of the glass columns; however, the roller waves also can increase the critical buckling force according to Euler. These specific factors of the glass specimens were measured by a new measurement method to analyse the effects of the imperfections on the load bearing capacity in case of a small amount of the specimens. The new method contains a Reference Point System and it is able to detect these imperfections in high accuracy. The new measurement method is also able to provide information about the glass manufacturing effects on the plate glass shape.

Keywords: glass, flexural buckling factors, own shape, tin-air side, reference point system
András JAKAB

PhD student at the BME, MSc Civil Engineer. Fields of interests: glass construction, glass columns, non-destructive testing methods, point-fixed glasses construction technology and management.

Salem Georges NEHME MSc Civil Engineer, PhD, Associate Professor at the Department of Construction Materials and Engineering Geology, Budapest University of Technology and Economics (BME). Member of the Technical committee of Glass Working Group (MSZT/MB 112) of Hungarian Standardization Institute; Hungarian Group of fib; Hungarian engineer chamber (MMK: 01-9159). Fields of interests: concrete technology, mass concrete, self-compacting concrete, fibre reinforced concrete, quality control of building materials, non-destructive testing, reinforced concrete structures, recycling of building materials.

\section{Introduction}

Despite the fact that there are a lot of negative criticism about the glass materials as load bearing material, the number of the enthusiastic researchers increases every year. Therefore, the material develops at high speed from many aspects. The stability issues of the glass structures are very popular topics nowadays. In the present paper the stability of the plate glass columns and their designing parameters are investigated.

The ideal central loading, the buckling phenomenon and the classical critical load have been known since Euler (Fig. 1, Eq. 1). The calculation method was just developed for different materials. In the last few years the researchers started to develop and modify the formulas for glasses as well. The imperfection of the glass can highly influence the buckling resistance. Therefore, it is preferred to take into account an initial " $w$ " displacement. Jan Belis et al. [1] already investigated the initial imperfections. Mean values were determined based on numerous large-scaled specimens and different measurement method. Products of different glass factories were tested, where differences were found, however measured values complied with the values of standards. The European standards set requirements $[2,3]$. The question is, which parameters are necessary or useless in the real formulas? Chiara Bedon and Claudio Amadio investigated a long time ago the possibility of design of glass structures with application of VEM models and laboratory experiments [4,5]. Roman Kalamar [6] investigated the load bearing capacity of glass hollow box columns. These researches demonstrate that the designing of glass columns - rather the designing of glass materials - became one of the most investigated topics.
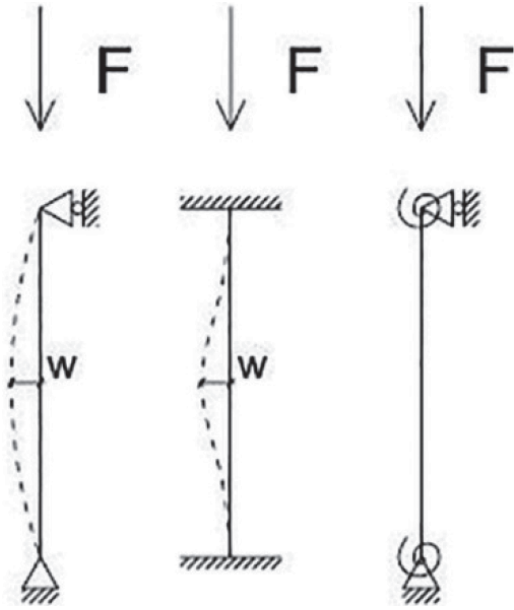

Fig. 1. Basic model for buckling of imperfect glass columns in case of pinned, fixed and flexible support

1. ábra Alap kihajlási modellek imperfect üvegoszlopk esetén csuklós, fix és rugalmas megtámasztással

$N_{c r}=\frac{\pi^{2} E I}{L^{2}}$

where:

$\mathrm{N}_{\mathrm{cr}}$ - critical buckling force

$\mathrm{EI}$ - bending stiffness

$\mathrm{L}$ - the freely rotated length of the columns

The stability issues of plate glass columns are investigated by the authors since 2012 on small-scaled specimens. In former researches the load bearing capacity, the typical crack patterns, 
the buckling phenomenon were determined [5,6,7]. The influence factors of $\mathrm{w}_{0}$ initial imperfection are investigated in the present paper. The design buckling curves formulas contain the $\mathrm{a}_{\text {imp }}$ and $\mathrm{a}_{0}$ factors in the Eq. 2 [8]. The initial imperfections are decisive point of the calculations the $\mathrm{a}_{\mathrm{imp}}$ factor contains it $\left(\mathrm{w}_{0}\right)$.

$\Phi=0,5\left[1+\alpha_{i m p}\left(\bar{\lambda}-\alpha_{0}\right)+\bar{\lambda}^{2}\right]$

where:

- $\Phi$ - buckling parameter of the buckling reduction factor $(\chi)$

- $\alpha_{\text {imp }}$ and $\alpha_{0}-$ shape factors

- $\bar{\lambda}$-slenderness

\section{Experimental test set-up and parameters}

Laboratory experiments were carried out in order to study the buckling behaviour of single and laminated glass columns. Specimens were examined with the application of Instron 5989 testing machine. The scales of the geometry of specimens (height, thickness, width) were selected based on existing glass columns from international and Hungarian realized projects. Test parameters of glass specimens were selected as the following:

Constants: test arrangement; support type; interlayer material (EVA foil with thickness of $0.38 \mathrm{~mm}$ ); edgework with polished edges; temperature $\left(+23 \pm 5{ }^{\circ} \mathrm{C}\right)$. Support: Height of fixing: $95 \mathrm{~mm}$; rubber plate (Shore A 80) was used between the steel supports and the glass.

Variables: type of glass layers: heat strengthened glass (HSG) / non heat-treated float glass (annealed glass); height of specimens: $1000 \mathrm{~mm}, 920 \mathrm{~mm}, 840 \mathrm{~mm}$; number of glass layers and the thickness of specimens: single layer: $8 \mathrm{~mm}, 12 \mathrm{~mm}$, $19 \mathrm{~mm}$; laminated glasses consisted of the following layers: $4.4 \mathrm{~mm}, 6.6 \mathrm{~mm}, 8.4 \mathrm{~mm}, 8.8 \mathrm{~mm}, 10.10 \mathrm{~mm}, 4.4 .4 \mathrm{~mm}$; glass width: $80 \mathrm{~mm}, 100 \mathrm{~mm}, 120 \mathrm{~mm}$; The rate of loading: $0.5 \mathrm{~mm} /$ $\mathrm{min} ; 1 \mathrm{~mm} / \mathrm{min}$.

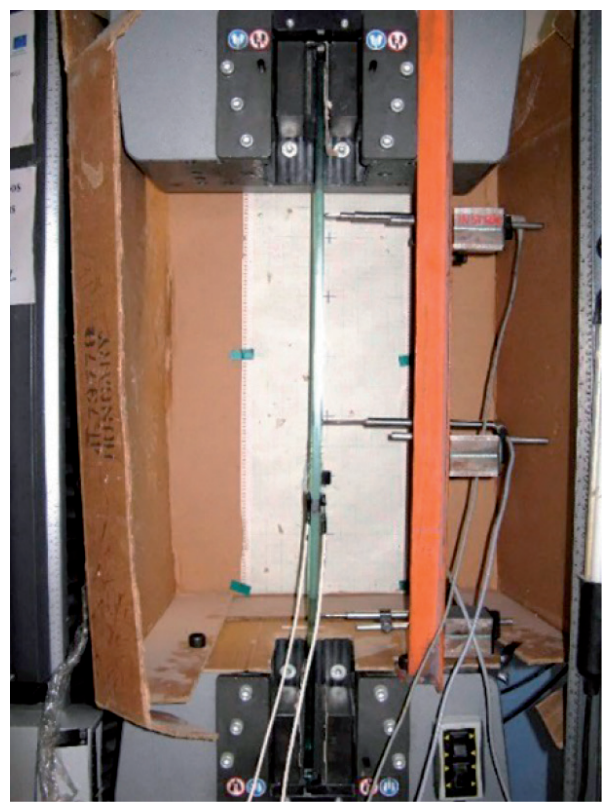

Fig. 2. The laboratory test set-up

2. ábra A kísérleti elrendezés
Simplified designations are used to distinguish between the studied specimens, these are e.g. H_2(4.4)_2_920_0.5: H, F: Type of glass: H - HSG; F - non heat-treated float glass; 2(4.4): Number of glass layers ex.: $4.4 \mathrm{~mm}$ laminated glass; 2: The number of specimen; 920 : Nominate height of specimen [mm]; 0.5: Rate of loading [ $\mathrm{mm} / \mathrm{min}]$. Abbreviations were used for the float laminated glass VG and for heat-strengthened laminated glass VSG. Although laminated glass with PVB interlayer foil and fully tempered glass (FTG) were not the part of the test parameters, a few pieces of these were tested as well.

The load and vertical displacement of the upper cross-head of the Instron 5989 universal testing machine were continuously measured. At three different heights the buckling displacement (horizontal displacement) of all specimens were continuously measured with HBM displacement transducers during the tests. Strains at center point on the surface of the glass panels were measured with HBM LY11-10/120 strain gauges. At least three specimens were tested at each testing combination. Laminated specimens were loaded until all glass layers were fractured (Fig. 2).

Until this moment more than 240 specimens were loaded until fracture, and more than 300 tests were carried out on these glasses including every type of tests: the axial vertical compressive tests until fracture or until the buckling phenomenon, compressive tests where the glasses were installed askew, specimens were loaded in horizontal direction at two different heights etc. The initial imperfections or own shape were measured in case of both sides of 22 glass specimens. These glasses were compressed twice. The ends of the glasses were not fixed in the steel shoes at the first test, when the specimen lost its stability, the test stopped. Both of the ends were fixed, so the area was filled out between the glass and the steel, at the second loading by the same specimen. At the second time the specimens were loaded until their fracture. The effects of the type of fixing can be studied on the buckling phenomenon without varying of the own shape of the specimen. Tin side detector was applied to determinate the types of sides in case of 102 specimens.

\section{Previous results}

\subsection{Determined stages in the loading behaviour}

Characteristic curves are presented in Fig. 3. as loading force vs. displacement (vertical, horizontal and deformations) diagrams to study the laboratory experimental results. Curves are categorized in three separate groups according to the numerous experimental results. Variation can be noticed in case of loading force vs. horizontal displacement diagrams. The characterization of the specimens depends on the stages of the loading history of the specimens. The name of stages are [7]:

- First stable stage

- Unstable stage

- Second stable stage

\subsection{Grouping of the glass specimens}

The first group contains all of the previously mentioned stages and in this group were experienced the highest bucking 
forces when compared to the other groups results. Force reduction can be observed on the vertical displacement diagrams in the buckling moment. Specific buckling point cannot be determined in case of the second group, the unstable stage disappears and after a stable section, the buckling is gradual. Only one stable stage can be observed in case of the third group, so the ultimate force (that is equal with the critical buckling force according to Euler) can be determined, but the force cannot be determined which belongs to the starting of the buckling (it is called buckling force) [9].

The results of the specimens had to be distinguished depending on the groups of buckling at the comparison of the influence of the variables. All of three types of buckling can easily occur at one testing combination (one type of glass specimen). Despite the fact that different buckling types and different buckling forces are experienced at one testing combination, ultimate forces are equal as shown in Fig. 3. The HSG can reach higher horizontal displacements and higher ultimate forces than the annealed glasses. However, the buckling forces of annealed and HSG scatter in the same range. The ranges are different for each testing combination. It also demonstrates that the ultimate limit state depends rather on the glass surface defects and on the glass strength, which can be increased by the heat strengthening. Furthermore, the buckling force depends rather on the imperfections. These experimental results mean that the type of buckling does not influence significantly the value of the ultimate force. These statements are demonstrated at the modelled small-scaled specimens. Probably the first group does not occur in case of real sized glass fins, the second group and most of all the third group occur more frequently.

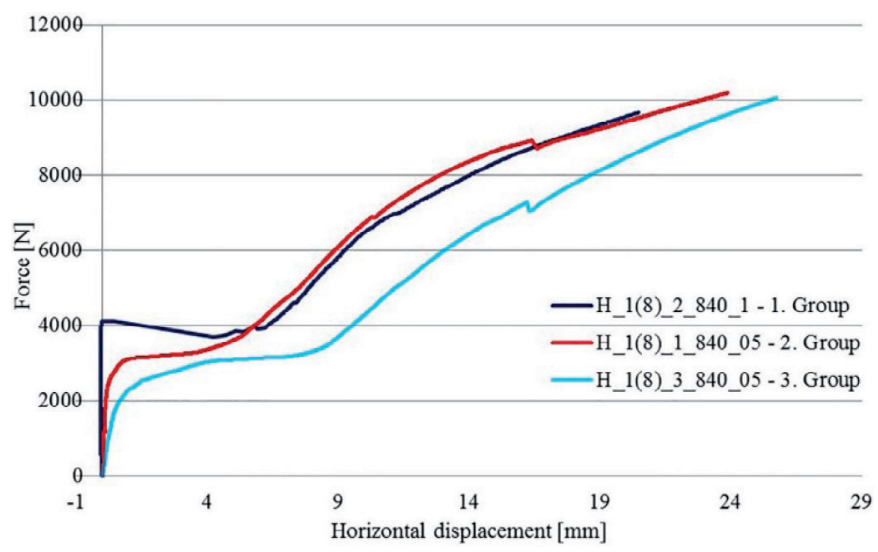

Fig. 3. The loading histories of glasses which belong to one testing combination 3. ábra Egy üvegcsoporthoz tartozó próbatestek különbözö terhelési története

\subsection{Standards and previous measurements of distortions}

The distortion of glass influences heavily the stability and load bearing capacity of the load bearing elements. The influencing distortions are the overall bow, roller wave distortion, edge lift or twisted initial imperfection according to the standard EN 1863-1 [2]. The sinus wave (roller), the overall bow and the loading process are presented until buckling in Fig. 4. This standard does not recommend definitely adequate measurement methodology. For instance, the measurement of roller wave is the following: use a straight edge and place it at right angles to the roller wave and bridging from peak to peak of the wave. However, this measurement does not provide continuous information about the shape of the specimen. This methodology seems simple and inaccurate to measure distortion below $1 \mathrm{~mm}$. The own shape initial imperfections need more information about the shape to take into account at the calculation of buckling. The shape of glass surface was measured by international researchers as well [1]. They applied the previous method and a continuous lineside methodology. The linear error meant the own shape of the auxiliary line structure, hence a displacement transducer was applied perpendicular to the surface, and it was moved along the glass.

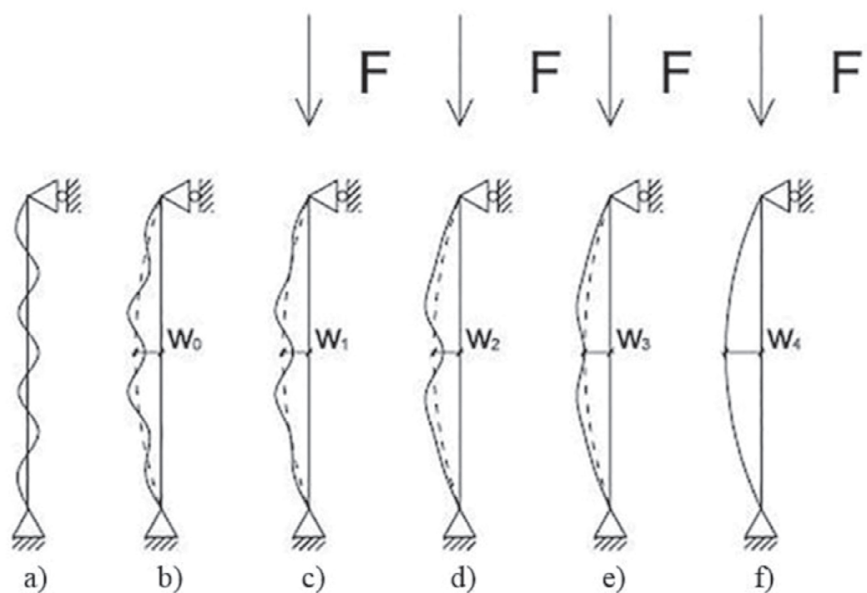

Fig. 4. Magnified roller wave and overall bow distortions of specimen. a) Unloaded specimen with sinus wave distortions $b$ ) unloaded specimen with sinus wave and overall bow distortions $c-e$ ) phenomenon of a compressed specimen before buckling f) buckled specimen $w_{-}=w_{0}+w$

4. ábra Nagyitott szinusz hullámok és kezdeti kihajlások a) Tehermentes próbatest szinusz hullámai b) tehermentes próbatest szinusz hullámokkal és kezdeti kihajlással c-e) kihajlás elötti alakváltozás nyomóvizsgálat esetén f) kihajlott próbatest $w_{4}=w_{0}+w_{t}$

\subsection{New measurement methodology}

In our measurement methodology, the glass was fixed and the Wenzel LH 108 3D Coordinate Measuring Machine was moving above of the glass (Fig. 5). The glass lied one of its side on the machine. The Metrosoft CM software was applied and micrometer was measured in high accuracy. Reference Point System was the most accurate method for the measurement.

The measurement methodology was the following: Three points were chosen from the four corner points on the surface area of the glass [10]. These points were base points of the measurement and they determine a plane. The different distance between the determined plane and the fourth point was divided between the 4 corner points, so a new plane was determined, in which is an average plane according to the four corner points it is called bestfit method. Three additional different base points were added in the two other axis: two points were perpendicular to the longitudinal axis and one parallel to the longitudinal axis. These points were needed to place the glass in three dimensions. The machine measured the glass waves perpendicular to the surface. The own shape, twisting and the other distortions were determined with the application of this measurement. The measured points were placed in three different lines, two lines were placed $15 \mathrm{~mm}$ 
from the edges in longitudinal direction. The third line was in the middle of the specimen. The measured points were placed $15 \mathrm{~mm}$ from each other in one line. The application of closer measuring point system does not increase the accuracy of the measuring only the measuring time. Three measured lines were applied in case of the $80 \mathrm{~mm}$ wide specimens.

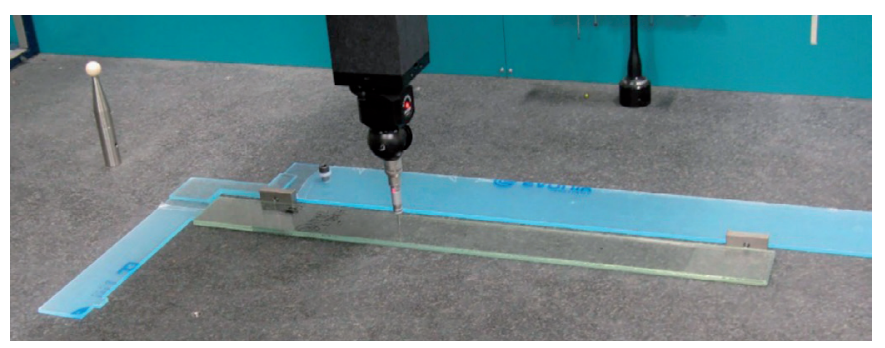

Fig. 5. Distortion measuring of glass specimen by the Wenzel LH 108 3D Coordinate Measuring Machine

5. ábra A Wenzel LH 108 3D Koordináta mérö müszerrel mért üvegek saját alak mérése

\section{The results of the distortion measurement}

\subsection{Prediction of the buckling direction}

The statements are drawn based on the distortion measurement results of 22 specimens. The measured points of the surface were integrated into different diagrams to show the own shape of the glasses. In general, the buckling direction of the specimens is occurred on the side where the higher values of sinus waves or overall bow were measured from the two sides. The statement proved to be true 8 and 6 times in case of the annealed glass and HSG. 3 and 5 times (annealed glass and HSG) the specimens buckled the other side where smaller measurement values were determined. The direction depends on the loading conditions and on the damping in the fixing area. In our laboratory test set-up, the last two conditions were constant, however the own shape of the specimens varied significantly at the tested specimens.

The reliability of the prediction of the buckling direction increased if the own shape is also taken into account next to the maximal overall bow and the mean sinus wave values. After the loading, the predicted direction was appropriate in case of 19 specimens from 22. These results indicate that the buckling direction is not predictable only based on the overall bow or sinus wave values. The whole shape of the glass should be known for the prediction of buckling direction.

\subsection{Results of the sinus wave values}

The applied sensitive measurement method enabled the authors to measure the smaller curves on the glass surfaces. It is already standardized that the heat strengthening procedure causes smaller curvatures which are called sinus waves (Figs. 6 and 7). The waves are formed when the heated glass plate - which was melted until the melting point - started to congeal and slightly formed on the ceramic rollers. The effect of the sinus wave can increase the buckling resistance in case of load bearing glass columns based on the basic Euler theory. Therefore, it is not easy to decide that altogether heat strengthened glasses are suitable materials for load bearing glass columns or not. Smaller curvatures can be observed in case of annealed glasses which cannot call sinus waves, because their distribution is unequal and their depth varied in larger range. The incidence of the smaller curvatures depends highly on the shape of the original glass plate (from where it was cut out) and the lamination procedure. Two glass plates, which had different own shapes, take on a new common shape after the lamination process, and this new common own shape will be independent. In Figs. 6 and 7 the measured own shapes are drawn by blue sign, however it is needed to magnify to be evaluable that is sign by red colour.

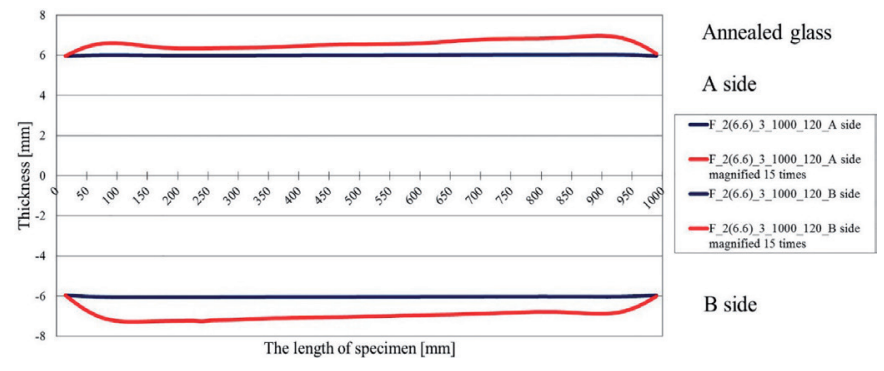

Fig. 6. Distortion measurement results in case of annealed laminated glass 6. ábra Egyrétegü float üveg saját alakja

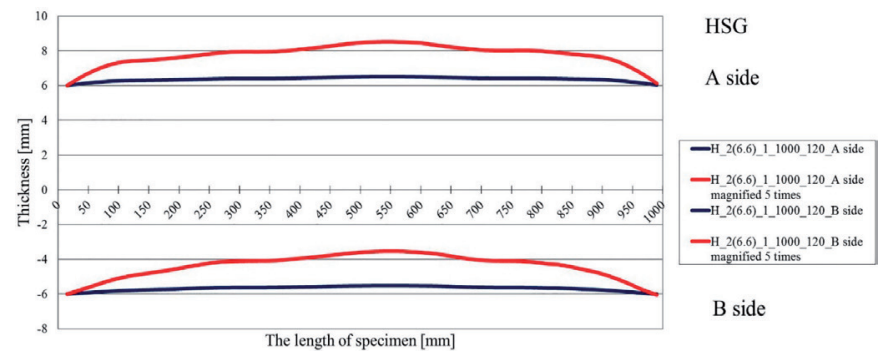

Fig. 7. Distortion measurement results in case of heat strengthened laminated glass 7. ábra Hökezelt üveg saját alakja

In Fig. 8 the absolute mean sinus wave values of the $120 \mathrm{~mm}$ width specimens can be observed. There were a few $80 \mathrm{~mm}$ width measured specimens as well. The values were measured on both sides of the glasses. Only 9 mean sinus wave values can be observed from 22 measurements in case of annealed glasses (the sinus wave of the annealed glass is not the typical wave phenomenon as in case of the HSG rather a similar surface property which is caused by the basic glass producing - floating - method). The mean sinus wave can be determined in all cases of the HSG. The depths of the sinus waves depend on the thickness (bending stiffness), heat strengthening and lamination process. The first conspicuous result is that the sinus wave values of the HSG are at least 3 times larger than the results of annealed glass. The maximal difference measured in case of the $80 \mathrm{~mm}$ width laminated glass consisted of two 6 $\mathrm{mm}$ layers where the sinus wave values of HSG were 17 times larger than the annealed glass. The number of the analysed specimens are not enough to determine accurate tendencies and correlations between the lamination, heat strengthening and the thickness. The conclusions need statistical evaluation as well due to the higher standard deviation of glass material. In former articles it was determined that the lamination process (also different lamination method) and heat strengthening increase the measured values, however that results cannot be seen due to the high standard deviation [10]. 


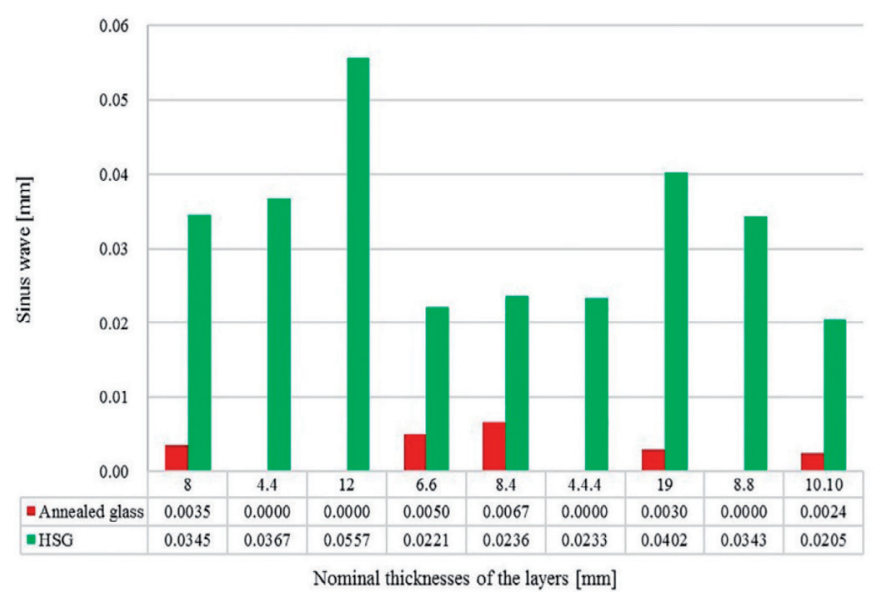

Fig. 8. Roller wave results in function of the nominal thicknesses of the layers

8. ábra Szinusz hullámok értékei a névleges vastagság függvényében

\subsection{Own shape results}

Between the specimens, there were similar and different figures based on the own shape results. Each own shape was compared to each other in the basic curvature. The own shapes of the annealed glasses were similar in 5 cases and different in 6 cases, while this ratio was 9 to 2 in case of the HSG. The effect of the heat strengthening procedure is that the own shape of glasses can be unified to a certain extent, however the overall bow and sinus wave values remain different, they cannot be unified due to the basic glass material differences (Figs. 6 and 7).

\subsection{Closing of the end of laminated annealed glass plates}

The two measured surfaces of a specimen were installed into one diagram, where it can be seen that the ends of the laminated glasses are closed in case of most of the annealed glasses, this phenomenon does not appear in case of HSG (Figs. 6 and 7). It can be observed in case of 6 annealed specimens and 1 HSG and it does not appear in case of 1 annealed and 6 HSG. The closing of the end of glass plates can be deduced to the lamination process. In the autoclave lamination system with EVA foil the pressure is generated by the air aspiration. It is interesting that the closing appears in case of annealed glasses but it cannot observe in case of HSG. Causes to be sought at the effect of the heat strengthening. The theoretical causes can be found at the unification glass plate by the heat strengthening which can fit better on each other and this fitting can be observed along the glass length while the own shape of annealed glass cannot fit on this low temperature and the applied pressure is only enough for the ending. The highest vacuum effect is at the glass edges, where the fitted HSG did not close in contrast to the annealed glass. The thickness of the specimens was measured by a calibrated calliper and a Bohle apparat (GlassBuddy Plus). The measured values did not show relevant differences between the devices, and differences cannot be observed between the HSG and annealed glass regarding the thicknesses.

\subsection{Overall bow}

The overall bow values can be seen in Fig. 9. These values are created from the average value of the maximal of the three measured lines. This average was necessary because the glass specimens had twisted own shape. The former wrote statements of the sinus wave are also true for the overall bow. Tendencies and correlations in function of the thickness and lamination cannot state that they are only predictable due to the high standard deviation of the glass material. It is also true that the overall bow values of the HSG glasses are general 10 times larger than the annealed glass values. The smallest difference was measured on laminated glasses which consisted two $4 \mathrm{~mm}$ thick glass layers, the value of the HSG specimen was $27 \%$ larger than the annealed specimen. The maximum overall bow of the HSG was 38 times larger than the annealed glass. The overall bow is influenced more by the own stresses of the specimens, the cutting out from the basic glass plate, the lamination process and the basic glass producing process. The overall bow is the highest if the specimen contains more HSG layers. It can be seen obviously that the lamination process increases the overall bow of the annealed glass, however this tendency cannot be observed in case of HSG due to the effect heat strengthening procedure. The effect of the lamination process caused at least $89 \%$ increasing based on the comparison of the measured overall bow values. The maximum difference was more than 6 times larger between the laminated and the single layered glass.

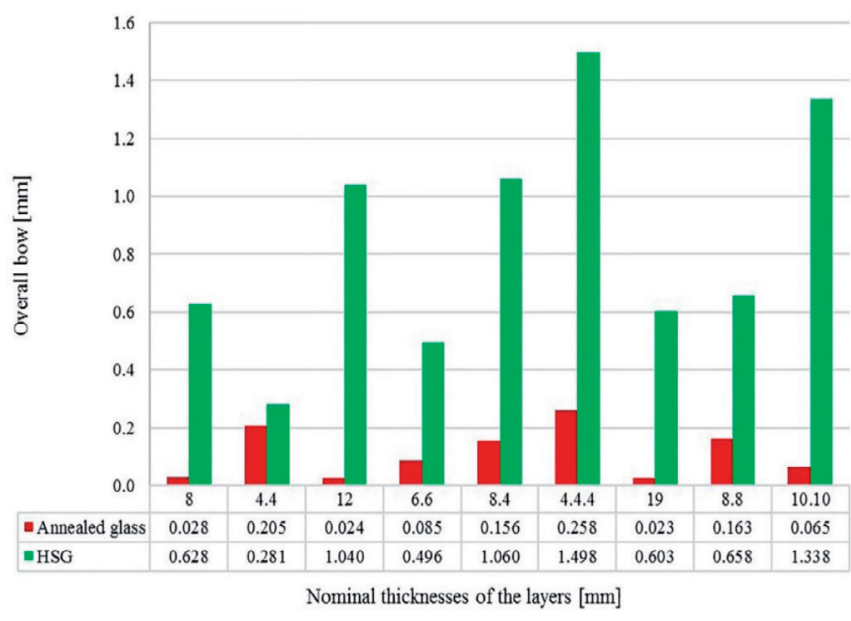

Fig. 9. Overall bow results in function of the nominal thicknesses of the layers 9. ábra Kezdeti kihajlások értékei a névleges vastagság függvényében

The overall bow and sinus wave values are given directly in $\mathrm{mm} / \mathrm{m}$ unit as in the standards, because the common height of the measured specimens was $1000 \mathrm{~mm}[2,3]$. Andreas Luible [11] provides in his thesis limits for initial deformation for annealed glass it was less $1 / 2500$ while sinusoidal distortion of HSG can be $1 / 300$ of the edge length $L[11,12]$. The size effect can also be caused by differences in the values if we compare the sinus wave and overall bow values which were measured by J. Belis et al. [1]. They determined L/400 initial imperfection when they analyzed different sized glasses with maximum length of $3000 \mathrm{~mm}$ for annealed glass and HSG. The limits of horizontally HSG are $3.0 \mathrm{~mm} / \mathrm{m}$ for overall bow and $0.3 \mathrm{~mm}$ roller wave according the standard EN 1863-1:2012 
[2]. However, our results reached only the half or less of these limits. The design parameters need sufficient safety factor, but the cost-effectiveness is also one of the most important goals in the building designing.

The maximal determined limits can be seen in Table 1 based on the laboratory measurements. The experienced values are less than the measured values of the other researchers.

\begin{tabular}{lcccc}
$\begin{array}{c}\text { Type of } \\
\text { distortions }\end{array}$ & $\begin{array}{c}\text { Type of } \\
\text { glasses }\end{array}$ & Single layer & $\begin{array}{c}\text { Laminated } \\
\text { consisted } \\
\text { of two } \\
\text { glass layers }\end{array}$ & $\begin{array}{c}\text { Laminated } \\
\text { consisted } \\
\text { of three } \\
\text { glass layers }\end{array}$ \\
\hline Overall bow & $\begin{array}{c}\text { Annealed } \\
\text { glass }\end{array}$ & $\sim$ L/35000 & $\sim$ L/4800 & $\sim$ L/3800 \\
\hline Overall bow & HSG & $\sim$ L/960 & $\sim$ L/740 & $\sim$ L/660 \\
\hline Sinus wave & $\begin{array}{c}\text { Annealed } \\
\text { glass }\end{array}$ & $\sim$ L/285000 & $\sim$ L/149000 & no data \\
\hline Sinus wave & HSG & $\sim$ L/17900 & $\sim$ L/27200 & $\sim$ L/42900
\end{tabular}

Table 1. Maximal determined limits for overall bow and sinus wave distortions in function of the number of the layers without statistical analyzing

1. táblázat A kezdeti kihajlás és a szinusz hullámok legnagyobb mért határértékei a hökezelés és a rétegszám függvényében statisztikai analizis nélkül

\section{Influence of the initial imperfection on the load bearing capacity}

\subsection{The basic influence factors of buckling}

The glass specimens were loaded by axial compression after their distortions have been measured. Thereby interesting conclusions can be drawn about the basic correlation between the measured own shape and the loading history including the buckling phenomenon. First of all, the key issue was: can the glass specimen be characterized by the sinus wave or by the overall bow for the buckling resistance design? If the answer is yes it means that few parameters are enough about the initial imperfection to design load bearing glass columns similarly as in case of the main construction materials ( $\mathrm{w}_{0}$ - limit). However, the answer is not based on the experimental results. The sinus wave and the overall bow are important data of the specimen, but the own shape provides relevant information about the glass specimen and for instance the buckling behaviour. The glasses consist of different waves, some are smaller and some are larger which seriously influence the buckling behaviour (Fig. 4). The buckling behaviour is also influenced by the stiffness of the fixing area, the bending stiffness of the glass and the skewness of the glass specimens. The human workers can also cause the reduction of the buckling resistance with mistakes at the adjusting. Therefore, the influencing factors are complex.

\subsection{Numbers of analysed specimens}

The buckling forces were determined in case of the first and second group based on the applied load vs. horizontal displacement diagrams. The maximal forces were easily determined if the specimens were loaded until fracture in case of all specimens. Further 44 specimens were tested next to the mentioned 22 specimens. Each type of specimen had two new pieces which were only compressed until fracture. The distortion measurement was done only on one specimen per groups and the most curved glasses were chosen with visual inspection from the groups. It means that the measured specimens are the most curved specimen with high probability. The selection was not random so the properties of rather curved glasses were investigated. The correlation can be nominated from this special aspect and newer conclusions can be drawn.

\subsection{Maximal forces and buckling forces}

The maximal forces were compared to each other in each type of groups. The maximal forces were close to each other in percentage, they varied between $82-125 \%$. It included the annealed glasses and HSG. However, the limit of these range is serviced by the annealed glass. The range is between $86-108$ $\%$ for HSG. These ranges are very close to each other compared to the buckling force ranges. The range of buckling forces were between $45-302 \%$ for annealed glass, and $28-217 \%$ for HSG. The annealed glass values move in wider range, the minimal percentage is greater, than the HSG minimal value therefore, the annealed glass can be a better choice for glass columns material from the approach of reliability of the buckling force. The annealed glasses bear the design load with higher probability without stability losing than the HSG columns in case of buckling resistance design of the plate glass columns. This designing theory is slightly confused because the HSG has higher energy dissipation, toughness that is an advantage over the annealed glass.

\subsection{Distortion effects on the maximal and the buckling forces}

The maximal forces were independent from the overall bow and sinus wave values. These results are represented with the small range and despite the fact that the chosen glasses were the most curved specimens from each group the maximal forces were close to each other. The similar groups, where the difference was only the heat strengthening, have similar maximal forces. A ratio was calculated from the annealed glass and HSG maximal forces, where 9 groups results were between $97-104 \%$ so in $7 \%$ and about $12 \%$ difference was determined at the further two groups. In case of the buckling forces the annealed glass results proved to be reliable. The range of the higher ratios is between $109-199 \%$ this range included 9 groups results the mean percentage was $160 \%$. In two cases the HSG had higher buckling forces than the annealed with 75 and $91 \%$. The annealed glass has higher buckling force based on the experimental results, this statement verifies that the resistance of the annealed glass is better for plate glass columns.

From the basic theory of buckling the buckling force is less in case of a curved glass. Lower buckling force can be measured where higher overall bow was measured, which characterizes theoretically the initial imperfection. After all that the maximal forces did not present high differences between annealed and HSG therefore the effects of the overall bow and sinus wave values can be analysed on these specimens. As it has been introduced in Figs. 8 to 9 the two types of distortions were about 10 times lower in case of annealed glass, where only the heat strengthening is the difference between the two types of glasses. It can be stated that the buckling force can be increased in case of lower overall bow and sinus wave values based on these 
results. The rate of reduction cannot be determined because more data is needed about similar specimens which belong to one group. However, it is already stated that the own shape of the specimens (smaller - larger waves) has greater influence on the buckling behaviour. There were a few annealed specimens as exceptions where the measured buckling force was less despite of the less overall bow and sinus wave values in comparison of their HSG pairs. Theoretically the sinus waves can increase the critical buckling force but the unloaded axis of the glasses are not necessary linear shaped as it can be seen in Fig. 4. In these cases, the sinus wave does not influence the buckling force. If the overall bow could be kept on a low value for instance on the values of the annealed glass, and the glass has sinus waves it is imaginable that the specimen belongs to the first class of buckling phenomenon and has higher buckling force.

\section{Experimental results and tin-air side correlations}

\subsection{Literature about tin-air side effects}

Before the compression tests the tin side was detected on numerous glass specimens by LED technology. The applied measuring device is the Bohle TinCheck apparat. The properties of the glass surface are different depending on the tin side or atmospheric (air) side. The authors are interested that are there any influence of the types of sides on the buckling phenomenon as well? Are there any correlations between the buckling direction, the surface distortion and the types of sides? The question is justified because in most of the cases the type of sides can change the efficiency of the glass processing works. For instance, the adhesion on the atmospheric side is more efficient than on the tin side [13]. Higher compressive surface stress develops on the atmospheric side than on the tin side in case of the chemically strengthening [14].

\subsection{Tin-air side effect on the buckling direction}

In the research the tin-air side effect was also investigated. Clear correlation cannot be detected between the type of glass side and the buckling direction based on the experimental results of 119 specimens. The main curves of the specimens were determined visually before the compression test. The specimens were inserted into the testing machine so that the proved buckling direction carries left to protect the sensitive devices on the right side viewed from the front (Fig. 2). Therefore, it formed more left buckled results than right. The glass sides were also laminated randomly. There are not clear results and tendencies. The distribution of the specimens formed similar in case of the left and right buckling direction in Table 2.

\begin{tabular}{ccccc}
$\begin{array}{c}\text { Buckling } \\
\text { direction }\end{array}$ & $\begin{array}{c}\text { Air-air } \\
\text { sides }\end{array}$ & $\begin{array}{c}\text { Air-tin } \\
\text { sides }\end{array}$ & $\begin{array}{c}\text { Tin-air } \\
\text { sides }\end{array}$ & $\begin{array}{c}\text { Tin-tin } \\
\text { sides }\end{array}$ \\
Left & 12 & 10 & 10 & 11 \\
\hline Right & 5 & 6 & 3 & 5 \\
Table 2. & $\begin{array}{l}\text { The number of left and right buckling direction of tested specimens depending } \\
\text { on the tin and air side of the laminated glass specimens consisted of two layers } \\
\text { (Annealed glass and HSG together). }\end{array}$ \\
2. táblázat & $\begin{array}{l}\text { A jobbra és balra kihajlott próbatestek darabszáma az ónos és a levegós oldal } \\
\text { függvényében }\end{array}$
\end{tabular}

\subsection{Tin-air side effect on the distortions}

The effects of the tin and air side were analysed based on the distortion measurement results. The number of the analysed specimens were low because only the 22 specimens were proper to analyse the distortion measurement results. Only those specimens could be analysed which had different sides - the single layer glasses and some laminated glasses and where sinus wave or overall bow results were measurable. Table 3 introduces the number of specimens which had higher distortion results depending on the heat strengthening effect and the proper side. An example: the overall bow data of the tin side were larger than the results of air side in case of 2 annealed specimens. It can be seen that there is no clear result to decide the standard phenomenon. Probably, these effects are not enough to change significantly the overall bow and sinus wave values of glasses, despite the fact that differences of the surface properties can be detected between the tin or atmospherically side. The results vary randomly.

\begin{tabular}{|c|c|c|c|c|}
\hline $\begin{array}{l}\text { Type of } \\
\text { glass }\end{array}$ & $\begin{array}{l}\text { Overall bow } \\
\text { and tin-side }\end{array}$ & $\begin{array}{l}\text { Overall bow } \\
\text { and air-side }\end{array}$ & $\begin{array}{l}\text { Sinus wave } \\
\text { and tin-side }\end{array}$ & $\begin{array}{l}\text { Sinus wave } \\
\text { and air-side }\end{array}$ \\
\hline Annealed & 2 & 3 & 1 & 1 \\
\hline HSG & 4 & 4 & 6 & 2 \\
\hline Table 3. & \multicolumn{4}{|c|}{$\begin{array}{l}\text { The number of the higher distortion values on the tin and air side in case of } \\
\text { annealed glass and HSG. }\end{array}$} \\
\hline 3. táblázat & \multicolumn{4}{|c|}{$\begin{array}{l}\text { A nagyobb felületi deformációkkal rendelkezö próbatestek darabszáma az } \\
\text { ónos vagy levegős oldalon az üvegek fajtájának függvényében }\end{array}$} \\
\hline
\end{tabular}

\subsection{Tin-air side effect on the own shape}

The own shapes of the right specimens - single layer or laminated glass with different type of sides - were analysed in function of the effects of the tin or air side. There were tendencies between the own shapes and the surfaces however the tendencies were caused rather by the heat strengthening and the lamination process. There was no phenomenon which is attributable to the tin-air effect, however it is possible that there are some effects at lower sizes which can influence the distortions of the specimens, but the extent of the effect is not measurable in the investigated range. It means that the role of tin-air effect is more important on the efficiency of lamination, adhesion and the surface strength of the glass structure designing than at the stability issues of glass columns.

\section{Conclusions}

Engineers have to calculate with the application of safe designing formulas and parameters which are serviced by the researchers in case of glass structures. The applied formulas and parameters have to be further developed to reduce the building costs. This approach helps the glass structures, designing and constructions to evolve unabated. New distortion measurement methodology was introduced to analyse the own shape, the sinus wave and overall bow values of plate glass columns. Both surfaces of 22 specimens were measured by the distortion measurement methodology which were also loaded by central compression until fracture. The measured results do 
not reach the limits of the overall bow and sinus wave based on the standards. Moreover, most of the results were less than the half of limits in the standards and in the literature. The overall bow depends on the one hand on the glass producing method and on the other hand on the size effect. The increasing of the length of glass causes the larger overall bow values. The results of HSG were about 10 times larger than the values of annealed glass. The maximal load of plate glass columns can be estimated more safely over the buckling force, where the annealed glass had larger and more reliable results than the HSG. Therefore, it can be stated that annealed glasses are more suitable for plate glass columns than HSG. The influence of the sinus wave and overall bow on the buckling force is less than the own shape of the specimen which can influence the buckling resistance of glasses to a great extent. The maximal load is totally independent of the distortion results. Therefore, it is recommended to introduce other parameters (for example the individual own shape of glasses) at the critical buckling force designing instead of the overall bow. Despite that the tinair effect causes differences on the properties of the glass sides it does not influence the buckling direction, the sinus wave, overall bow and the own shape results. Considering these statements, it can be concluded that the effect of the tin and air side is negligible at the load bearing capacity of glass columns and at the buckling force as well compared to the other factors which are more relevant: heat strengthening, the own shape of glass, gravity, the fixing area and the human impacts. The benefits of these results that engineers do not have to pay attention to the type of sides of glass plates during the designing and construction processes on the buckling point of view.

\section{Acknowledgements}

Authors express their gratitude to Rákosy Glass Ltd. for providing the specimens. Authors are thankful to the Department of Construction Materials and Technologies, BME for the technical support. The distortion measurement support is gratefully acknowledged to Balázs Petróczi, who is CAD Development engineer of Salgglas Ltd.

\section{References}

[1] Belis, J. - Mocibob, D. - Luible, A. - Vandebroek, M. (2011): On the size and shape of initial out-of-plane curvatures in structural glass components, Construction and Building Materials 25, 2700-2712. https://doi.org/10.1016/j.conbuildmat.2010.12.021

[2] EN 1863-1:2012, Glass in building - Heat strengthened soda lime silicate glass - Part 1: Definition and description.

[3] EN 572-2:2013, Glass in building - Basic soda lime silicate glass products - Part 2: Float glass.

[4] Amadio, C. - Bedon, C.(2010): An analytical model for buckling evaluation of laminated glass beams in bending and compression. Proceedings of XXV. A.T.I.V. International Conference. Glass, when Technology Meets Design.

[5] Bedon, C. - Amadio, C. (2012): Buckling Verification of Laminated Glass Elements in Compression. JCES Volume 1, Issue 3. pp. 90-101.

[6] Kalamar, R. - Bedon, C. - Eliasova, M. (2016): Experimental investigation for the structural performance assessment of square hollow glass columns. Engineering Structures 113. pp. 1-15.

https://doi.org/10.1016/j.engstruct.2016.01.028
[7] Jakab, A. - Nehme, K. - Nehme, S.G. (2015): Laboratory Experiments of Centrally Loaded Glass Columns, GPD - Glass Performances Days. Tampere, Finland, ISBN: 978-952-5836-03-5, 117-121.

[8] Bedon, C. - Amadio, C. (2016): Design buckling curves for glass columns and beams. Structures and Buildings. Volume 168 Issue SB7. pp. 514-526. https://doi.org/10.1680/stbu.13.00113

[9] Jakab, A. - Nehme, K. - Nehme, S. G. (2015): Stability Questions of Centrally Loaded Glass Columns, METNET Annual Seminar in Budapest, Hungary, 7-17. ISBN 978-951-784-762-9

[10] Jakab, A. - Nehme, K. - Nehme, S. G. (2016): Classification of "I" - shaped glass columns, CCC2016 Proceedings. ISBN: 978-615-5270-24-6 pp. 78-83. https://doi.org/10.1016/j.proeng.2016.11.608

[11] Luible, A. (2004): Stabilitat von Tragelementen aus Glas, These EPFL 3014, Ecole polytechnique federale de Lausanne (EPFL), Lausanne

[12] Luible, A. (2005): Plate Buckling of Glass Panels, GPD - Glass Performance Days

[13] Mognato, E. - Schiavonato, M. - Pittoni, M. (2015): Chemically Strengthened Glass: correlation between Surface Compression, Potassium Profile, Mechanical Strength and production parameters, GPD - Glass Performance Days. Tampere, Finland, ISBN: 978-952-5836-03-5, pp.411-415.

[14] Stahldanke, C. - Sehati, P. - Sundberg, P. - Mattsson, L. - Siovall, P. Albinsson, O. - Lundevall, A. (2015): The influence of surface composition and plasma treatment on adhesion, GPD - Glass Performance Days. Tampere, Finland, ISBN: 978-952-5836-03-5, pp. 266-269.

$\underline{\text { Ref.: }}$

Jakab, András - Nehme, Salem Georges: Influencing factors of the plate glass columns on the load bearing capacity Építőanyag - Journal of Silicate Based and Composite Materials, Vol. 70, No. 2 (2018), 62-69. p. https://doi.org/10.14382/epitoanyag-jsbcm.2018.12

\section{Sík lapokból álló üvegoszlopok teherbírását} befolyásoló tényezők

A statikai számításokban figyelembe vesszük a tervezés során a szerkezeti elemek kezdeti imperfekcióját. Az üvegszerkezetek esetében kezdeti imperfeckiók lehetnek lokális vagy globális hibák, amik jelentôsen tudják csökkenteni a teherbírási kapacitást és a használhatósági határállapotot. Az általános építôanyagok esetében a stabilitási tervezés tartalmazza a kezdeti görbületet és imperfekciót, amiknek a figyelembe vett értéke függ az elem keresztmetszetétôl. A teherbíró üvegszerezetek tervezése még mindig újdonságnak számít, azonban alkalmazandó határértékeket már megfogalmaztak. Több mint 240 kisméretû „l” keresztmetszetú üvegpróbatest vizsgálatán alapuló kísérletben vizsgáljuk a rugalmas kihajlás tulajdonságait. A kísérletek során az egyik legfontosabb tényezô volt a kezdeti imperfekció. A kezdeti kihajlás és a szinusz hullámok alapvetôen kedvezôtlenül befolyásolják az üvegoszlopok teherbírását, azonban a szinusz hullámok hatása akár növelheti is az Euler-i kihajlási ellenállást a rúdban található szinusz hullámok számának növelésével. A kezdeti imperfekciókat és a vizsgált próbatestek saját alakját egy új mérési módszerrel vizsgáltuk, amiben referencia pontrendszert alkalmaztunk a lehetố legnagyobb mérési pontosság érdekében. A méréssorozatban az üvegfeldolgozási munkák a próbatesteken végzett hatásait is vizsgáltuk.

Kulcsszavak: üveg, kihajlást befolyásoló tényezôk, kezdeti alak, ónnal és levegôvel érintkezô felület, referencia pontrendszer 